\begin{tabular}{|c|c|c|}
\hline & Int.J.Curr.Microbiol.App.Sci (2021) 10(09): 254-261 & \\
\hline & $\begin{array}{l}\text { International Journal of Current Microbiology and Applied Sciences } \\
\text { ISSN: 2319-7706 Volume } 10 \text { Number } 09 \text { (2021) } \\
\text { Journal homepage: http://www.ijcmas.com }\end{array}$ & $\begin{array}{l}\$ 9 \\
\Rightarrow 3\end{array}$ \\
\hline $\begin{array}{l}\text { EXCELLENT } \\
\text { PUBLISHERS }\end{array}$ & & www.ijemas.com \\
\hline
\end{tabular}

\title{
Microbiological Analysis of Tucumã Pulp (Astrocaryum aculeatum Meyer) Commercialized at Fairs in the City of Manaus
}

\section{Luana Lopes Casas ${ }^{1 *}$, Rherysonn Pantoja de Jesus ${ }^{1}$, Lucas Nascimento de Almeida ${ }^{2}$, Pedro de Queiroz Costa Neto ${ }^{2}$ and Samaroni Adilson Moreira Corrêa ${ }^{3}$}

\author{
${ }^{1}$ Department of Pharmacy, Estácio Amazonas College, Manaus, 69050-001, Brazil \\ ${ }^{2}$ Department of Agricultural Sciences, Federal University of Amazonas, \\ Manaus, 69067-005, Brazil \\ ${ }^{3}$ Senior High School Vasco Vasques, Manaus, 69088-474, Brazil
}

*Corresponding author

\section{A B S T R A C T}

Keywords

Quality, Coliforms, Amazon, tucumanzeiro

Article Info

Accepted:

15 August 2021

Available Online:

10 September 2021
The tucumanzeiro is a palm tree of the Arecaceae family, and Astrocaryum aculeatum is the best known and most appreciated species. The fruit called tucumã has a significant cultural and economic value, and despite being widely consumed, the pulp of this fruit has a relatively short shelf life. At fairs, it is possible to see the pulp being stored inappropriately, contributing to the proliferation of microorganisms. Given the importance of this fruit for local trade, this study aimed to investigate the microbiological profile of tucumã pulp sold in the main fairs in Manaus. The pulps were obtained from 18 points of sale divided between the six zones of the city. The samples were placed in a thermal box and submitted to microbiological analysis. The microorganisms evaluated were coliforms (AOAC 991.14), Escherichia coli (AOAC 991.14), Salmonella spp. (ISO 6579), molds and yeasts (APHA 21:2015) in triplicate. The results showed that 13 samples showed coliform growth with amounts ranging from $6.4 \times 10$ to $1.2 \times 10^{4}$ CFU/g. Regarding the amount of yeast, only three samples showed results above what is considered ideal for fruit pulps. Samples that showed growth for molds were within the permissible microbiological limits. None of the samples showed growth for E. coli and Salmonella spp.

\section{Introduction}

The Amazon is well known for its diversity of both fauna and flora. It presents a wide variety of fruits with local economic potential and, among these, tucumã stands out (Braga et al.,
2010). The tucumanzeiro (Astrocaryum aculeatum G. Mey) is a palm with great economic potential due to its various uses (Xisto, 2020). One of the main ways of using the tree is to obtain the fruits. In the municipality of Manaus, tucumã - the fruit of 
the tucumanzeiro - has greater preference and consumption, arousing interest in the cultivation of the species (Flor, 2013).

There are two ways in which the fruit is generally sold: (i) in nature, sold in a dozen or a hundred; and (ii) locally processed by the traders themselves, where the pulp is sold by weight. As it is a regional product of forest origin, it is rarely sold in supermarkets, but it is abundant in open markets, markets, and strategic points of sale on the streets of Manaus, where it can be found during much of the year (Costa et al., 2005; Didonet and Ferraz, 2014). Tucumã pulp is consumed in nature, accompanied by manioc flour, as a sandwich and in the form of juices and ice cream (Moussa and Kahn, 1997).

Among the desirable attributes in tucumã pulp is the microbial quality within the standards required by Normative Instruction (NI) $n^{\circ} 60$, of December 23, 2019, and by NI $n^{\circ} 1$ of 2000 (Brazil, 2019; Brazil, 2000; Flor, 2013).

Despite being widely consumed, the pulp of this fruit has a relatively short shelf life. According to Schroth et al., (2004), when obtaining the tucumã pulp, it must be consumed in one day, at room temperature, or in one week, under refrigeration. However, what can be seen in the fruit pulp trade is quite different from what is recommended by scientific studies.

For Azevedo et al., (2017), it is possible to verify the tucumã pulp being stored in inadequate conditions, a fact that contributes to the proliferation of microorganisms and the development of food-borne diseases (DTA). Among the microorganisms that cause DTA are coliforms, Salmonella spp., molds, and yeasts. Faced with this problem, this study aimed to investigate the microbiological profile of tucumã pulps sold in the main fairs in Manaus.

\section{Materials and Methods}

\section{Sample Collection}

The samples of tucumã (Figure 1) previously fractionated were acquired at fairs and stalls in six different areas of Manaus (North, East, South, West, Center-South, and Center-West) which were identified as follows:

North - Point 4 (P4), Point 15 (P15), Point 16 (P16).

East - Point 5 (P5), Point 6 (P6), Point 14 (P14).

South - Point 3 (P3), Point 9 (P9), Point 10 (P10), Point 11 (P11), Point 12 (P12), Point 13 (P13).

West - Point 8 (P8).

Center-South - Point 17 (P17), Point 18 (P18).

Midwest - Point 1 (P1), Point 2 (P2), Point 7 (P7).

From each zone, points of sale of tucumã pulp were randomly chosen for analysis. The samples were transported in thermal boxes for immediate processing at the Microbiology Laboratory of Estácio Amazonas College.

\section{Microbiological Evaluation}

\section{Coliforms and Escherichia coli}

The method used was the Petrifilm ${ }^{\mathrm{TM}}$ plate for counting E. coli/Coliforms (AOAC Methods 991.14 and 998.08) (Silva et al., 2017). $25 \mathrm{~g}$ of sample were weighed and added to a flask containing $225 \mathrm{ml}$ of Phosphate Buffer. After homogenization, the plate was placed on a flat surface, the top film was lifted and the volume of $1 \mathrm{ml}$ of the solution was deposited. After waiting 2-5 minutes, the plates were incubated 
in a bacteriological incubator at $35 \pm 1{ }^{\circ} \mathrm{C}$ for 24 hours. After incubation, only typical colonies with the following characteristics were counted: total coliforms, all red, blue, or bluish-red colonies with gas bubbles, and $E$. coli only blue or bluish-red colonies with gas bubbles. As there was no development of typical E. coli colonies within 24 hours, the plates were reincubated to repeat the count at 48 hours. The result was expressed in a colony-forming unit (CFU) per gram of sample $(\mathrm{CFU} / \mathrm{g})$.

\section{Salmonella spp.}

The method used was the Petrifilm ${ }^{\mathrm{TM}}$ Salmonella Express System Plate (ISO 6579 Method) (Silva et al., 2017). $10 \mathrm{~g}$ of sample was weighed, added in a flask with $90 \mathrm{ml}$ of Supplement Enrichment Broth for Salmonella spp. and the homogenized solution. The flask with this solution was incubated in a bacteriological incubator at $41.5^{\circ} \mathrm{C} \pm 1{ }^{\circ} \mathrm{C}$ for 24 hours.

Petrifilm $^{\mathrm{TM}}$ plates were prepared by aseptically adding $2 \mathrm{ml}$ of sterile distilled water to each plate and stored at room temperature $\left(25^{\circ} \mathrm{C}\right)$ for 1 hour in the dark. At the end of the hydration period of the plates, $10 \mu \mathrm{l}$ of the sample were removed from the bottle containing Enrichment Broth and carefully striated on the surface of the plate. Plates were incubated at $41.5^{\circ} \mathrm{C} \pm 1^{\circ} \mathrm{C}$ for 24 hours. After this period, the typical colonies with the following characteristics were presumptively quantified: red colonies with yellow zones and associated gas bubbles, red colonies with yellow zones, and red colonies with gas without surrounding yellow zones.

For biochemical confirmation, the Petrifilm ${ }^{\mathrm{TM}}$ Salmonella Express System disc was used. On the plate with grown colonies, the top film was lifted and the confirmation disc was carefully inserted. The upper film was placed again, taking care to remove the excess bubbles resulting from the procedure. Plates were incubated again at $41.5^{\circ} \mathrm{C} \pm 1^{\circ} \mathrm{C}$ for 4 hours and typical colonies were quantified. Only dark blue/black colonies with blue precipitate and dark blue/black colonies with a dark red center and blue precipitate were considered. The result was expressed in the $\mathrm{CFU} / \mathrm{g}$ of a sample.

\section{Molds and Yeasts}

The method used was counting molds and yeasts in Dicloran Rose Bengal Chloramphenicol Agar - DRBC (APHA Method 21:2015) (Silva et al., 2017). $25 \mathrm{~g}$ of sample were weighed and added to a flask containing $225 \mathrm{ml}$ of $0.1 \%$ peptone water. The solution was homogenized, and then serial dilutions were made up to $10^{-3} .0 .1 \mathrm{ml}$ of the $10^{-3}$ dilution was transferred to Petri dishes with about $20 \mathrm{ml}$ of DRBC agar where the inoculum was spread with Drigalski loop. After 15 minutes the plates were incubated without inverting at $25 \pm 1{ }^{\circ} \mathrm{C}$ for 7 days in the dark. After this period, the colonies grown were counted by separating molds and yeasts. The result was expressed in the CFU/g of a sample.

Test results for the search for Salmonella spp. and $E$. coli were analyzed based on NI $n^{\circ} 60$ of 2019 (Brazil, 2019) that establishes the lists of microbiological standards for foods. The results of coliforms, molds, and yeasts were analyzed as established in NI $n^{\mathbf{0}} 1$ of 2000 (Brazil, 2000), which determines identity and quality standards for fruit pulps.

\section{Results and Discussion}

Microbiological analyzes revealed the presence of coliforms, yeasts, and filamentous fungi (Table 1) in the evaluated samples. No samples were contaminated by Salmonella spp. and E. coli. Coliform bacteria are defined 
as facultative anaerobic, gram-negative, nonspore-forming rods that ferment lactose vigorously in acid and gas at $35^{\circ} \mathrm{C}$ in 24 or 48 h (Halkman and Halkman, 2014). Coliform bacteria generally belong to four genera of Enterobacteriaceae: Citrobacter freundii, Enterobacter cloacae, Enterobacter aerogenes, E. coli and Klebsiella pneumoniae.

Although NI $\mathrm{n}^{\circ} 60$ does not set limits for coliforms, most samples had significant amounts of bacteria from this group. The NI $\mathrm{n}^{\circ} 1$ of 2000 (Brazil, 2000) determines identity and quality standards for some fruit pulps. Although tucumã is not on the list, the Amazonian fruit of the same botanical family as the açaí (Euterpe oleracea Mart.) that is described in the IN can serve as a basis for evaluating the microbiological profile of the tucumã. Among the analyzed tucumã pulps, it was found that there was a significant growth of coliforms in samples P1, P2, P4, P7, P8, P9, P11, P12, P14, P15, P16, P17, P18. The high number of these microorganisms indicates that the circumstances are suitable for the presence of enteric pathogens and may mean insufficient sanitary conditions in the processing and/or packaging of the fruits. This type of problem can be easily solved with the adoption of good manufacturing practices combined with the quality of storage of this type of input. Azevedo et al., (2017) verified that the use of vacuum packaging, associated with freezing, allows the preservation of the main nutritional characteristics of tucumã pulp in nature, for 30 days of storage.

An alternative for using the pulp more efficiently was also presented by Yuyama $e t$ al., (2008) who suggested the application of dewatering and spraying methods. Through periodic tests, they concluded that dehydrated and pulverized tucumã pulp, regardless of the type of packaging and storage temperature, could be stored and consumed for up to 150 days, while maintaining its nutritional and microbiological potential.

Other Amazonian fruit pulps have also been studied for the presence of microbiological contaminants associated with the lack of application of good sanitary practices. Santos et al., (2016), when evaluating samples of açaí pulp, an Amazonian fruit that is widely consumed in the form of juices, they also found bacteria from the coliform group, including E. coli, in about $35 \%$ of the samples.

Costa et al., (2020) analyzing açaí samples in five open markets in Manaus, found that all were unfit for consumption due to the presence of pathogenic bacteria. A similar result was observed by Jones and Lemes (2014) who found $83.3 \%$ of samples contaminated even in açaí pulps that underwent pasteurization process. Santos and Nascimento (2014) also found coliforms above the allowed limit in acerola, bacuri, cupuaçu and guava pulps.

Molds and yeasts are considered a group of quality indicator microorganisms, being slightly related to inadequate manufacturing practices. In this context, high counts of this group of microorganisms can lead to a reduction in the shelf life of the product, because of food deterioration, and consequently, significant economic losses to the production chain (Moraes and Machado, 2021).

Yeast and mold counts are more relevant indicators of a shelf life than bacteria. They are commonly listed in foods as quality indicators. Yeasts are a common cause of food spoilage, especially in acidic foods such as fruits and fruit juices (Halhman and Halkman, 2014). 
Table.1 Microorganisms quantified in tucumã pulps from different parts of the city of Manaus.

\begin{tabular}{|c|c|c|c|c|c|}
\hline Sample & E. coli & Salmonella & $\begin{array}{c}\text { *Coliforms } \\
\text { (CFU/g) }\end{array}$ & $\begin{array}{l}* \text { Yeasts } \\
(\text { CFU/g) }\end{array}$ & $\begin{array}{l}\text { *Molds } \\
\text { (CFU/g) }\end{array}$ \\
\hline P1 & Absent & Absent in $25 \mathrm{~g}$ & $2.7 \times 10^{3 * *}$ & $2.6 \times 10$ & 0 \\
\hline $\mathbf{P 2}$ & Absent & Absent in $25 \mathrm{~g}$ & $3.5 \times 10^{3 * *}$ & $5.2 \times 10$ & $1.3 \times 10^{-2}$ \\
\hline P3 & Absent & Absent in $25 \mathrm{~g}$ & 0 & $7.6 \times 10^{3 * *}$ & $1.0 \times 10^{2}$ \\
\hline P4 & Absent & Absent in $25 \mathrm{~g}$ & $4.0 \times 10^{3 * *}$ & $6.0 \times 10^{2}$ & $2.6 \times 10^{-2}$ \\
\hline P5 & Absent & Absent in $25 \mathrm{~g}$ & 0 & $5.6 \times 10^{2}$ & $1.2 \times 10$ \\
\hline P6 & Absent & Absent in $25 \mathrm{~g}$ & 0 & $1.2 \times 10^{4 * *}$ & 0 \\
\hline P7 & Absent & Absent in $25 \mathrm{~g}$ & $2.9 \times 10^{3 * *}$ & 0 & 0 \\
\hline P8 & Absent & Absent in $25 \mathrm{~g}$ & $1.2 \times 10^{2 * *}$ & $2.6 \times 10$ & 0 \\
\hline P9 & Absent & Absent in $25 \mathrm{~g}$ & $4.0 \times 10^{* *}$ & 0 & 0 \\
\hline P10 & Absent & Absent in $25 \mathrm{~g}$ & 0 & 0 & 0 \\
\hline P11 & Absent & Absent in $25 \mathrm{~g}$ & $4.0 \times 10^{3 * *}$ & $3.6 \times 10^{2}$ & 0 \\
\hline P12 & Absent & Absent in $25 \mathrm{~g}$ & $1.2 \times 10^{4 * *}$ & $2.5 \times 10^{2}$ & $2.6 \times 10^{-2}$ \\
\hline P13 & Absent & Absent in $25 \mathrm{~g}$ & 0 & 0 & 0 \\
\hline P14 & Absent & Absent in $25 \mathrm{~g}$ & $6.4 \times 10^{* *}$ & 0 & 0 \\
\hline P15 & Absent & Absent in $25 \mathrm{~g}$ & $8.0 \times 10^{* *}$ & 0 & 0 \\
\hline P16 & Absent & Absent in $25 \mathrm{~g}$ & $1.2 \times 10^{4 * *}$ & $1.2 \times 10^{4 * *}$ & 0 \\
\hline P17 & Absent & Absent in $25 \mathrm{~g}$ & $6.4 \times 10^{2 * *}$ & $9.0 \times 10$ & 0 \\
\hline P18 & Absent & Absent in $25 \mathrm{~g}$ & $1.2 \times 10^{4 * *}$ & $2.5 \times 10^{2}$ & 0 \\
\hline
\end{tabular}

*There is no standard in NI $\mathrm{n}^{\circ} 60$ of 2019

**Samples that presented values above what is considered safe for some fruit pulps (Brazil, 2000).

Fig.1 Tucumã samples obtained for the experiment
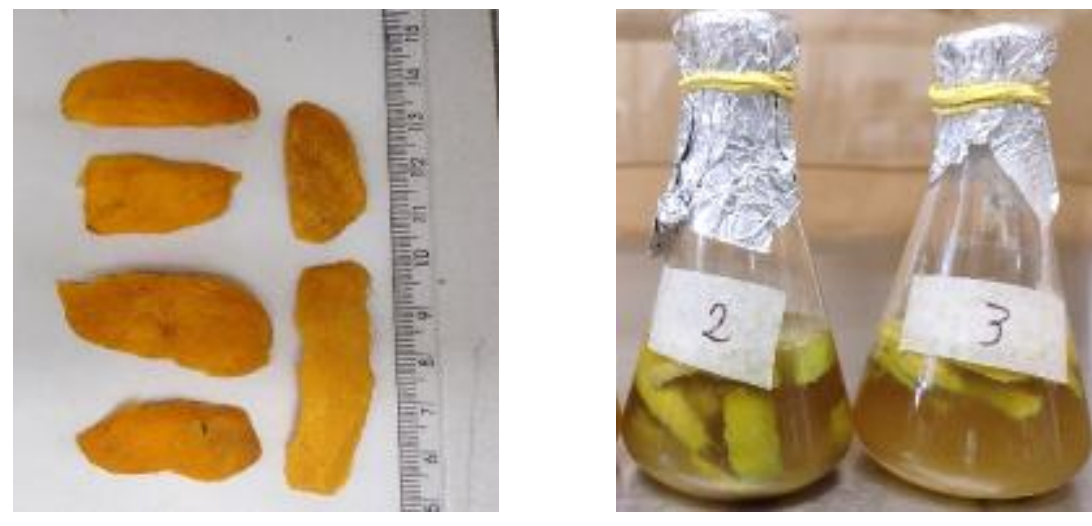

A - Packages containing tucumã pulp obtained at fairs. B - Tucumã pulp. C - Erlenmeyer flasks with $25 \mathrm{~g}$ of sample in $225 \mathrm{ml}$ of Phosphate Buffer. 
Fig.2 Dichloran Rose Bengal Chloramphenicol (DRBC) agar plates after 7 days of incubation
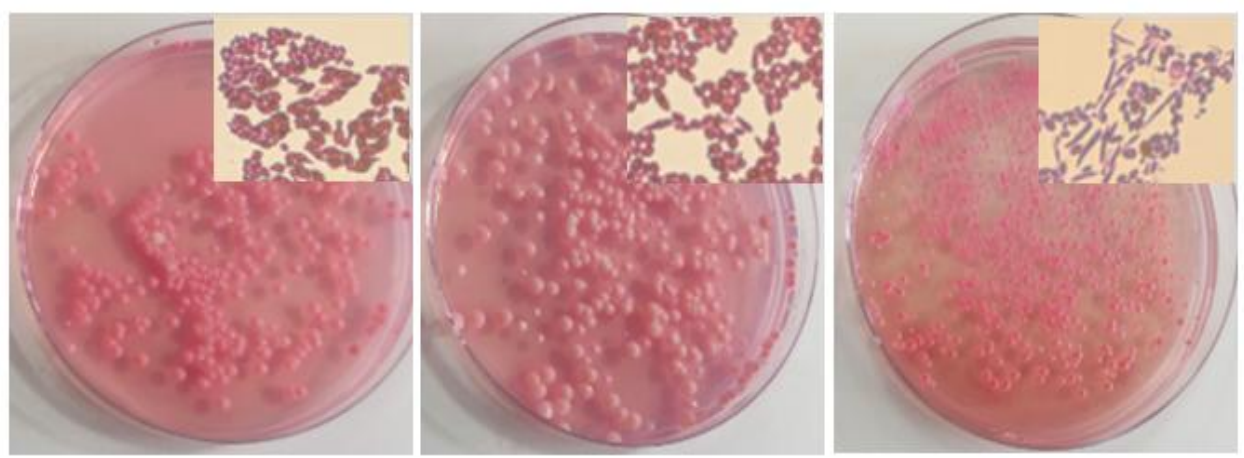

Yeast isolated from samples. A - Sample P3. B - Sample P6. C - Sample P16. Highlights, yeast microscopy at $100 \mathrm{X}$ magnification.

Fig.3 Some fungi isolated from tucuma pulp

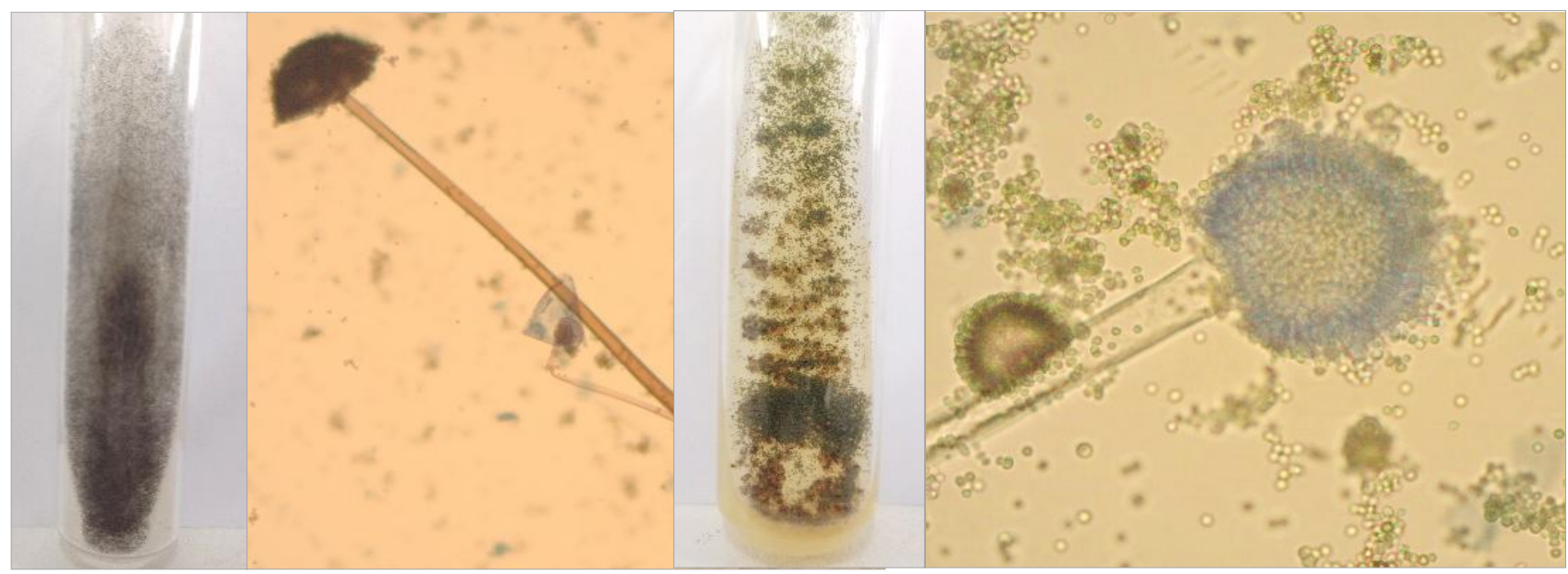

Fungi isolated from the samples. A - Sample P4. B - Sample P12. Highlights, microscopy of filamentous fungi at 40X magnification

In the present work, only $33.3 \%$ of the analyzed tucumã samples showed negative results for yeast growth (Table 1). The IN $n^{\circ}$ 60 also does not set limits for the presence of molds and yeasts in fruit pulps however Brazil (2000) establishes for some fruit pulps that values above $5.0 \times 10^{3} \mathrm{CFU} / \mathrm{g}$ (or $\mathrm{CFU} / \mathrm{ml}$ ) may not be considered safe. Evaluating from this perspective, only samples P3, P6, and P16 (Figure 2) could be considered unfit for consumption.

Although fungi do not cause infection through food, some strains can produce mycotoxins, which can cause serious chronic illness if consumed. As quality indicators, they can be used to assess ingredient acceptability, organoleptic characteristics, stability, and shelf life of a product (Halhman and Halkman, 2014).

Furthermore, the presence of certain species of filamentous fungi such as Penicillium, Aspergillus, and Fusarium can result in serious damage due to their ability to produce mycotoxins (Moraes and Machado, 2021). In this work, only samples P2, P3, P4, P5, and P12 showed the growth of filamentous fungi 
(Figure 3). Despite these results, according to NI $n^{\circ} 1$ from 2000 (Brazil, 2000) all samples are within the microbiological limits established for molds.

The results demonstrate that, despite the samples complying with the microbiological standards of NI $n^{\circ} 60$ of 2019 regarding the absence of E. coli and Salmonella, it is necessary to implement good manufacturing practices. This is because a good part of the samples was not within the microbiological standards defined by NI ${ }^{\circ} 1$ of 2000 regarding the presence of coliforms and yeasts in fruit pulps. For this reason, works such as this one highlights the importance of constant microbiological surveillance to prevent possible outbreaks of food-borne diseases (DTA).

\section{Acknowledgement}

The authors are grateful for the financial support provided by the Estácio Amazonas Faculty's Research Productivity Program through a scholarship.

\section{References}

Azevedo, S. C. M., Vieira, L. M., Matsuura, T., Silva, G. F., Duvoisin Junior, S., Albuquerque, P. M. (2017). Study of the conservation of the nutritional properties of in natura Tucumã pulp (Astrocaryum aculeatum) using vacuum packaging. Brazilian Journal of Food Technology, 20:1-9.

Braga, A. C. C., Silva, A. E., Pelais, A. C. A., Bichara, C. M. G., Pompey, D. R. (2010). Antioxidant activity and quantification of bioactive compounds from abricó fruits (Mammea americana). Food and Nutrition, 21(1): 31-36.

Brazil (2020). Ministry of Agriculture, Livestock and Supply. Normative
Instruction $\mathrm{n}^{\mathrm{o}}$ 01, of January 7, 2000. Approves identity and quality standards for fruit pulps.

Brazil (2019). National Health Surveillance Agency. Normative Instruction $n^{\circ}$ 60, of December 23, 2019. Lists of microbiological standards for foods.

Costa, J. R.; Leeuwen, J.; Costa, J. A. (2005). Tucumã from Amazonas: Astrocaryum tucuma Martinus. In: Shanley, P., Medina, G. (Ed.), Frutíferas e plantas úteis na vida amazônica. Belém: CIFOR \& Iamazon, pp. 209-222.

Costa S. C. F. C., Gomes M. C. F., Erazo R. L., Carvalho E. B. S.; Alencar Y. B. (2020). Analysis of the microbiological quality of açaí pulps commercialized in five free fairs in the city of Manaus. Brazilian Journal of Development, 6(7):47667-47677.

Didonet, A. A., Ferraz, I. D. K. (2014). Fruit trade of tucuma (Astrocaryum aculeatum G. Mey - Arecaceae) at local market-places in Manaus (Amazonas, Brazil). Brazilian Journal of Fruitculture, 36(2):353-362.

Flor, N. S. (2013). Pulp conservation and preparation of tucumã paste (Astrocaryum aculeatum G. Mey.). Thesis, National Institute of Amazonian Research, Manaus, Brazil.

Halkman, H. B. D., Halkman, A. K. (2014). Indicator Organisms. In: Batt, C. A., Tortorello, M. L. (Ed.), Encyclopedia of Food Microbiology, Second Edition, Elsevier, pp.358-363.

Jones, L. C., Lemes, R. M. L. (2014). Microbiological analysis of açaímarketed in a city of southern Minas Gerais - Brazil. Vale do Rio Verde University Magazine, 12(2): 601-608.

Moraes J. O., Machado M. R. G. (2021). Microbiological quality of fruit pulp in Brazil: An overview of the years 2010 through 2020. Research, Society and Development, 10(7):1-19. 
Moussa, F., Kahn, F. (1997). Uso y potencial economico de dos palmas, Astrocaryum aculeatum Meyer y A. vulgare Martinus, em la Amazonía brasileña. In: Rios, M., Pedesen, H.B. (Ed.), Uso y manejo de recursos vegetales. Quito: Abya-Yala, pp. 101-116.

Santos, W. C., Nascimento, A. R. (2014). Microbiological characterization of four regional fruit pulp sold in market places of San Luis/MA. Research Notebooks, 21:1-7.

Santos, B. A., Campofiorito, M. C. M., Pinto, J. F. L., Penteado S. H. N. W., Affonso Fonseca, F. L. A., Gehrke F. S. (2016). Microbiological analysis of the acai berry products marketed in the city of São Paulo. Brazilian Journal of Clinical Analysis, 48(1):53-57.

Schroth, G., Mota, M. S. S., Lopes, R., Freitas, A. F. (2004). Extractive use, management and in situ domestication of a weedy palm, Astrocaryum tucuma, in the central Amazon. Forest Ecology and Management, 202(1-3):161-179, 2004.

Silva, N., Junqueira, V. C. A.; Silveira, N. F. A., Taniwaki, M. H., Gomes, R. A. R., Okazaki, M.M. (2017). Manual of methods for microbiological analysis of food and water. 5th. São Paulo: Blucher, pp. 117-137.

Xisto, G. J. (2020). Postharvest conservation of tucumã fruit (Astrocaryum aculeatum G. Meyer) as a function of ripening stage and storage atmosphere. Thesis, National Institute of Amazonian Research, Manaus, Brazil.

Yuyama, L. K. O., Maeda, R. N., Pantoja, L., Aguiar, J. P. L., Marinho, H. A. (2008). Processing and shelf-life evaluation of dehydrated and pulverized tucuman (Astrocaryum aculeatum Meyer). Food Science and Technology, 28(2): 408412.

\section{How to cite this article:}

Luana Lopes Casas, Rherysonn Pantoja de Jesus, Lucas Nascimento de Almeida, Pedro de Queiroz Costa Neto and Samaroni Adilson Moreira Corrêa. 2021. Microbiological Analysis of Tucumã Pulp (Astrocaryum aculeatum Meyer) Commercialized at Fairs in the City of Manaus. Int.J.Curr.Microbiol.App.Sci. 10(09): 254-261. doi: https://doi.org/10.20546/ijcmas.2021.1009.029 